\title{
First morphological characterization of autochthonous olive (Olea euro- paea L.) denominations from central and eastern of Algeria
}

\author{
Rachid BOUKHARI ${ }^{1,2}$, Abdelkader AMEUR AMEUR ${ }^{3}$, Hocine INNAL ${ }^{4}$, Semir Bechir Suheil GAOUAR ${ }^{3}$ \\ Received October 13, 2020; accepted November 24, 2020. \\ Delo je prispelo 13. oktobra 2020, sprejeto 24. novembra 2020.
}

First morphological characterization of autochthonous olive (Olea europaea L.) denominations from central and eastern of Algeria

Abstract: Olive (Olea europaea L.) resources in Algeria are very little investigated. In fact, a total of 60 denominations have been the subject of characterization studies and they are cited in the bibliography but only 36 varieties are described and listed in the catalog of Algerian varieties of olive tree. In this work, a study on the diversity by mean of a field survey followed by morphological characterization, an estimate of the Shannon diversity index of a set of denominations collected in central and eastern of Algeria were carried out. The survey allowed us to note the existence of 33 denominations never mentioned in the bibliography. Morphological characterization based on the characteristics of tree, fruit and endocarp allowed us to a morphological description of 23 denominations. The Principal Component Analysis, Multiple Correspondence Analysis and Ascending Hierarchical Classification analysis allowed us to classify them into a few groups. The value of the relative diversity of all denominations is slightly below the average $(0.42)$. The results obtained in this work provide very useful information on certain morphological characteristics of the studied denominations and indicate the critical conditions in which several denominations are found, which constitutes a great risk of genetic erosion.

Key words: denominations; diversity; genetic erosion; morphological characterization; olive tree; survey
Prvo morfološko ovrednotenje samoniklih akcesij oljk (Olea europaea L.) iz osrednje in vzhodne Alžirije

Izvleček: Populacije oljke (Olea europaea L.) so v Alžiriji slabo preučene. Dejansko je bilo celokupno preučenih le 60 akcesij, ki so navedene v literaturi, a od teh je bilo opisanih le 36 sort, ki so navedene v katalogu alžirskih oljčnih sort. $\mathrm{V}$ tej raziskavi je pregledu diverzitete na terenu sledila raziskava morfoloških lastnosti in določitev Shannonevega indeksa raznolikosti akcesij nabranih v osrednji in vzhodni Alžiriji. Na osnovi raziskave smo lahko zabeležili 33 novih tipov, ki še niso bili omenjeni v literaturi. Morfološko ovrednotenje je temeljilo na znakih kot so lastnosti drevesa, ploda in endokarpa, kar nam je omogočilo morfološki opis 23 tipov. Z analizo glavnih component, korespondenčno analizo in analizo hierarhične klasifikacije smo te akcesije lahko razvrstili v pet skupin. Vrednost relativne raznolikosti je za vse akcesije nekoliko pod poprečjem $(0,42)$. Rezultati, pridobljeni $\mathrm{v}$ tej raziskavi, dajejo koristne informacije o morfoloških lastnostih preučevanih akcesij in nakazujejo kritične razmere, $v$ katerih so bile številne akcesije najdene, kar predstavlja veliko tveganje za genetsko erozijo.

Ključne besede: akcesije; raznolikost; genetska erozija; morfološka oznaka; oljka; pregled

1 High school of agronomy, Laboratory of biotechnology applied to agriculture and environmental preservation, Mostaganem, Algeria

2 Corresponding author, e-mail: boukharach@gmail.com

3 University Abu Bakr Belkaid, Laboratory of Physiology, Physiopathology and Biochemistry of Nutrition (PPABIONUT), Tlemcen, Algeria

4 Institut technique des arbres fruitiers et de la vigne (ITAFV), Algeria 


\section{INTRODUCTION}

Algeria, like all Mediterranean countries, has a long history with olive (Olea europaea L.) growing. With its high diversity of bioclimatic stages, it constitutes a large reservoir of olive resources. In fact the western region is dominated by the Sigoise variety and some introduced varieties, but the central and eastern regions have a very high varietal richness.

In general, confusions about cultivar names exist in all olive-growing countries (Trujillo et al., 2013). Synonymies (different names for the same cultivar) and homonyms (the same name for different cultivars) are extremely common among and in olive-growing countries (Barranco et al., 2000a).

Several morphological characterization studies on Algerian olive resources are carried out but very few of them are published (Mendil and Sebai, 2006; Sidhoum and Gaouar, 2013; Sidhoum and Gaouar, 2017; Boucheffa et al., 2018; Sidhoum et al., 2018; Abdessemed et al., 2018; Boukhari and Gaouar, 2018). Hauville (1953) reported the presence in Algeria of 150 olive cultivars more or less abundant. A project entitled "Conservation, Characterization, Collection and Use of Genetic Resources of the Olive Tree", launched by the International Olive Council, led to the characterization and conservation of 36 local cultivars listed in the catalog of Algerian olive varieties (Mendil and Sebai, 2006). During the last ten years, several studies of genetic characterization by molecular markers have been carried out on Algerian olive resources. These studies allowed to characterize a set of 60 cultivars (Dominguez-Garcia et al., 2011; Haouane et al., 2011; Trujillo et al., 2013; Abdessemed et al., 2015; Boucheffa et al., 2016; Boucheffa et al., 2018; Di Rienzo et al., 2018). However,-these numbers seems to be very far from the actual number of cultivars existing in Algeria: first, comparisons between the results that had been obtained in these different works are essential in order to detect probable cases of synonymies and/or homonyms. Secondly, several other older native denominations exist in different regions and remain uncharacterized, unexploited and threatened with extinction. Thus, on one side, among several traditional olive-growing regions in central and eastern Algeria (such as Tizi-ouzou, Bejaia, Setif, Skikda, Guelma, Batna and El Taref), there are a considerable number of cultivars with unique characteristics which never cited in the bibliography. On another side, historical events experienced by Algeria through the ages (conquests and migrations of populations) have allowed the olive tree to settle in regions distant from the Mediterranean basin in semi-arid to arid climates. Nowadays, we find in some remote corners of the high plateaus stripped of all perennial vegetation, many vestiges of ol- ive presses dating from the Roman era while the olive oil was the subject of an intense trade between Algeria and Rome (Alloum, 1974). The availability of subterranean water resources in these areas is also a key factor in the development of this crop. This is the case of the regions of Khirane and Zaouia (Wilaya of Khenchela) and Ain Zaatout (village of Ath Ferrah, Wilaya of Biskra) (located between latitudes $35^{\circ} 09^{\prime} \mathrm{N}$ and $34^{\circ} 54^{\prime} \mathrm{N}$ ) where this crop is known since at least the Roman era, which is attested by the presence of old oil mills and trees several centuries and millennia (Camps-Fabrer, 1954). These cultivars are very important for their adaptation to the semi-arid and arid climate of the region and their agronomic characteristics as well as their socio-economic and ecological interest for the region.

The great lack of information on the diversity of this crop and the accelerated climate change experienced by Algeria, coupled with mismanagement problems at the olive grower scale (inappropriate conduct, lack of production tools and modern knowledge) and also at the level of the central and local administration (encourage the cultivation of certain Algerian cultivars like Chemlal or introduced to the detriment of native cultivars, absence of efficient national program of preservation of the plant genetic resources etc ...), threaten the varietal richness by the risk of the disappearance of old cultivars with restricted diffusion which may have very interesting characteristics of production, quality, resistance, and adaptation. The problem resides in the permanent loss of some of the olive resources that are still poorly known and whose consequences are not sufficiently evaluated at present.

Native cultivars are important not only for the preservation of biodiversity but also for their specific adaptation to local growing conditions (Poljuha et al., 2008). In this context this study works on highlighting the following objectives: prospecting as well as morphological characterization of olive resources in central and eastern of Algeria in order to provide more information on the actual state of olive diversity in Algeria. This is an essential element for the establishment of possible preservation and genetic improvement programs.

\section{MATERIALS AND METHODS}

\subsection{STUDY AREAS, FIELD SURVEYS AND SAM- PLING}

The field trips were made with the help of the Technical Institute of Fruit Tree and Grapevine (ITAFV) in different regions of the center and east of the country (El Taref, Bouira, Setif, Tizi- ouzou, Bejaia, Khenchela, 


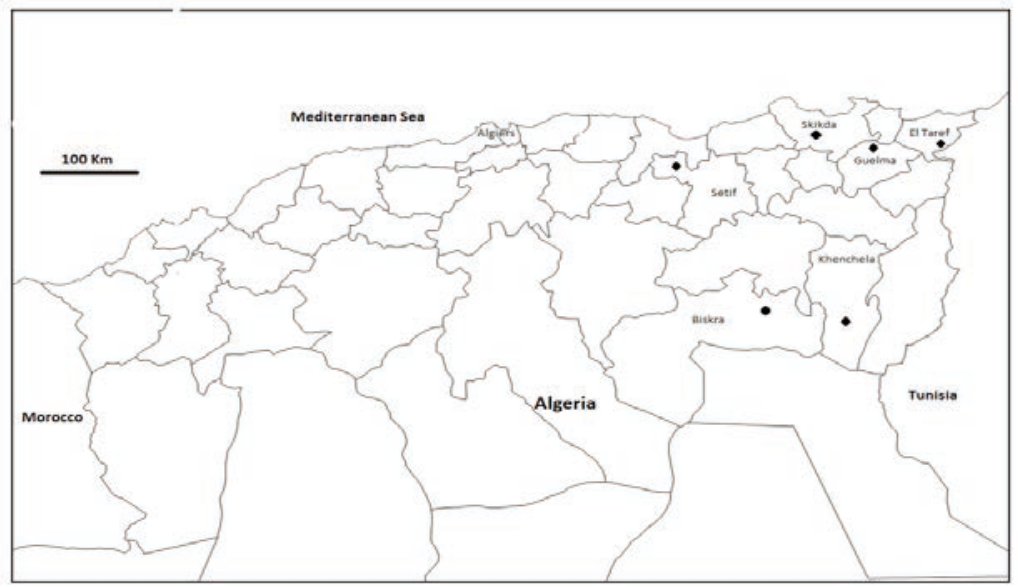

Figure 1: Sampling areas

Table 1: GPS coordinates and irrigation conduct of the study areas

\begin{tabular}{|c|c|c|}
\hline Areas & GPS location & Irrigation \\
\hline Ain Zaatout (Biskra) & $35^{\circ} 08^{\prime} 40,4^{\prime \prime} \mathrm{N} 5^{\circ} 49^{\prime} 58,8^{\prime \prime} \mathrm{E}$ & Insufficient gravity irrigation \\
\hline Khirane (Khenchela) & $35^{\circ} 00^{\prime} 16,4^{\prime \prime} \mathrm{N} 6^{\circ} 45^{\prime} 18,6^{\prime \prime} \mathrm{E}$ & Insufficient gravity irrigation \\
\hline Zaouia (Khenchela) & $34^{\circ} 57^{\prime} 40,0^{\prime \prime} \mathrm{N} 7^{\circ} 02^{\prime} 10,6^{\prime \prime} \mathrm{E}$ & Insufficient gravity irrigation \\
\hline Beni Meloul (Setif) & $36^{\circ} 23^{\prime} 10,8^{\prime \prime} \mathrm{N} 5^{\circ} 01^{\prime} 10,9^{\prime \prime} \mathrm{E}$ & Without irrigation \\
\hline Fedj Ziadi (El Taref) & $36^{\circ} 25^{\prime} 09,7^{\prime \prime} \mathrm{N} 8^{\circ} 18^{\prime} 40,9^{\prime \prime} \mathrm{E}$ & Without irrigation \\
\hline Gastu (Skikda) & $36^{\circ} 42^{\prime} 18,6^{\prime \prime} \mathrm{N} 7^{\circ} 17^{\prime} 56,7^{\prime \prime} \mathrm{E}$ & Without irrigation \\
\hline Josef (Skikda) & $36^{\circ} 37^{\prime} 19,1^{\prime \prime} \mathrm{N} 6^{\circ} 48^{\prime} 57,8^{\prime \prime} \mathrm{E}$ & Without irrigation \\
\hline Fejouj (Guelma) & $36^{\circ} 36^{\prime} 26,2^{\prime \prime} \mathrm{N} 7^{\circ} 20^{\prime} 05,4^{\prime \prime} \mathrm{E}$ & Without irrigation \\
\hline
\end{tabular}

Biskra, Skikda and Guelma) during the harvest period and during two successive olive growing seasons (20142016). The geographic positions of the study areas are shown in Figure 1.

The GPS coordinates as well as the irrigation conduct of the study areas, are summarized in Table 1 . This step allowed us to record and collect samples of all unknown denominations and to have data on the cradle of each denomination, its distribution and its agronomic potential, as well as the local know-how that will be useful for better preservation and use of the resource.

\subsection{MORPHOLOGICAL CHARACTERIZATION}

The morphological characterization concerned the quantitative and qualitative descriptors of the tree, the fruit and the endocarp described in the methodology established by the International Olive Council in its methodology for the primary characterization of olive varieties. Observations and measurements were made on 40 fruits and 40 endocarps of each tree at the rate of 5 trees per denomination. Twenty five (25) characters from the tree, fruit and endocarp were used in this study, of which 10 are quantitative and 15 are qualitative (Table 3). Analysis of variance (ANOVA), homogeneous groups $($ alpha $=0.05)$, principal component analysis $(\mathrm{PCA})$ and ascending hierarchical classification (AHC) were calculated using Statistica V10 software while the multiple correspondence analysis (MCA) was performed by Xlstat (2014).

Moreover, In order to estimate the phenotypic diversity of quantitative traits, the Shannon-Weaver index (Shannon and Weaver, 1964) is calculated on the basis of the frequencies of the classes corresponding to each trait.

The Shannon-Weaver index is given by the following formula:

$$
H=-\sum_{i=1}^{n} \mathrm{Pi} \operatorname{Ln} \mathrm{Pi}
$$

Pi: frequency of class $i$ $\mathrm{n}$ : number of individuals of a class in the sample A value of the relative diversity index $(J)$ is obtained 
Table 2: List of the 23 denominations studied

\begin{tabular}{|c|c|c|}
\hline & Denomination & Abbreviation \\
\hline 1 & Ahia ousbaa & AHIA \\
\hline 2 & Akenane & AK \\
\hline 3 & Alslith & ALS \\
\hline 4 & Azeboudj de Ain Zaatout & AZB-AZ \\
\hline 5 & Azeboudj Boudhoudhane & AZB-B \\
\hline 6 & Azeboudj de Khirane & AZB-K \\
\hline 7 & Azeboudj de Elouandoura & AZB-E \\
\hline 8 & Azizawth & AZIZ \\
\hline 9 & Balbal & BAL \\
\hline 10 & Barouni & BAR \\
\hline 11 & Abeskri de Ain Zaatout & ABS \\
\hline 12 & Blanquette de Gastu & B-GASTU \\
\hline 13 & Bouchouka & BOUCH \\
\hline 14 & Bouguenfou & BOUG \\
\hline 15 & Chetoui & CHET \\
\hline 16 & Derdi & DER \\
\hline 17 & Guerboua & GUER \\
\hline 18 & Melissi & MEL \\
\hline 19 & Rougette de Fejouj & R-FEJOUJ \\
\hline 20 & Serti & SERT \\
\hline 21 & Taliani & TAL \\
\hline 22 & Serradj & SERR \\
\hline 23 & Azerradj de Ain Zaatout & AZR \\
\hline
\end{tabular}

by dividing the value of $(H)$ on its maximum value Hmax $(H \max =\operatorname{Ln}(\mathrm{n}))$ :

$$
J=\frac{H}{H \max }
$$

\section{RESULTS AND DISCUSSION}

\subsection{FIELD PROSPECTING}

The field prospecting that we carried out led us to record the existence of 59 denominations other than the 36 varieties already described in the catalog of Algerian olive varieties. 33 of them have not been the subject of any study and are never cited in the bibliography $\left({ }^{(b)}\right.$ in Table 4) and 23 of them were considered in our study (d) in Table 4).

This study has allowed us to highlight that: (1) the presence in some olive-growing regions (El Tarf, Bouira,
Table 3: List of studied characters

\begin{tabular}{|c|c|c|}
\hline \multicolumn{2}{|c|}{ Organs } & Characters \\
\hline \multirow{12}{*}{ 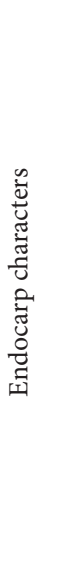 } & $\mathrm{PN}$ & Endocarp mass \\
\hline & $\mathrm{LN}$ & Endocarp length \\
\hline & $\mathrm{DN}$ & Endocarp width \\
\hline & $\mathrm{LN} / \mathrm{DN}$ & Length to diameter ratio of the endocarp \\
\hline & SyAN & Symmetry in the A position of the endocarp \\
\hline & SyBN & Symmetry in the B position of the endocarp \\
\hline & PDmaxN & Position of the maximum diameter of the endocarp \\
\hline & FsomN & Form of the summit of the endocarp \\
\hline & FbaseN & Form of the base of the endocarp \\
\hline & SurfN & Surface of the endocarp \\
\hline & NS & Number of furrows \\
\hline & ESN & End of the summit of the endocarp \\
\hline \multirow{10}{*}{ 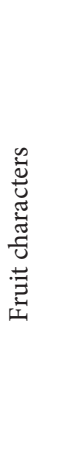 } & $\mathrm{PO}$ & Fruit mass \\
\hline & $\mathrm{LO}$ & Fruit length \\
\hline & DO & Width of the fruit \\
\hline & $\mathrm{LO} / \mathrm{DO}$ & Length to diameter ratio of the fruit \\
\hline & SyAO & Symmetry in the A position of the fruit \\
\hline & $\mathrm{PDmaxO}$ & Symmetry in the B position of the fruit \\
\hline & FsomO & Form of the summit of the fruit \\
\hline & FbaseO & Form of the base of the fruit \\
\hline & Mam & Presence of the nipple \\
\hline & RPN & Pulp / endocarp ratio \\
\hline \multirow{3}{*}{ 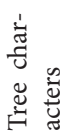 } & Vig & Vigor of the tree \\
\hline & DensF & Density of foliage \\
\hline & Port & The port of the tree \\
\hline
\end{tabular}

Setif, Tizi-ouzou, Bejaia, Skikda and Guelma) of several denominations not known until now. (2) There are several small isolated historical areas of olive growing in the region of southern Aurés (semi-arid to arid climate regions) as Khirane (wilaya of Khenchela) and Ain Zaatout (wilaya of Biskra) rich in olive resources not yet recorded.

The olive tree has practically disappeared today from the Aurasian landscape (the Aurés region) although 150 years ago it was still very much alive below $1000 \mathrm{~m}$, the presence of numerous ruins of presses throughout the massif up to the altitude of $1500 \mathrm{~m}$ seems to indicate that the culture of this tree was very developed there in Antiquity (Morizot, 1993).

It is to highlight that new plantings have been put in place, in several regions of the country, during the last two decades in the framework of several programs for the establishment of 1.000 .000 hectares of olive tree: PPDRI (Proximity Rural Development Project) FNRDA (National Regulatory Fund and agricultural development) PSD (Sector Development Program) (Frah et al., 
Table 4: List of Algerian olive resources

\begin{tabular}{|c|c|c|c|c|c|}
\hline $\mathrm{N}^{\circ}$ & Denomination & Area & $\mathrm{N}^{\circ}$ & Denomination & Area \\
\hline 01 & Abani ${ }^{a . c}$ & Khenchela & 49 & Bouichret ${ }^{\mathrm{a} \cdot \mathrm{c}}$ & Bejaia \\
\hline 02 & Aberkane $^{\text {a.c }}$ & Bejaia & 50 & Boukaïla ${ }^{\text {a.c }}$ & Constantine \\
\hline 03 & Abeskri de Ain Zaatout ${ }^{\mathrm{b} . \mathrm{d}}$ & Biskra & 51 & Bouricha $^{\text {a.c }}$ & Skikda \\
\hline 04 & Abeskri de Khirane ${ }^{c}$ & Khenchela & 52 & Braouki $^{c}$ & Skikda \\
\hline 05 & Aedli ${ }^{b}$ & Tizi-ouzou & 53 & Chemlal ${ }^{\mathrm{a} . \mathrm{c}}$ & Kabylie \\
\hline 06 & Aelah $^{\text {a.c }}$ & Khenchela & 54 & Chetoui $^{\mathrm{cd}}$ & Skikda \\
\hline 07 & Aghchren de Titest ${ }^{\text {a.c }}$ & Setif & 55 & Derdi b.d & Skikda \\
\hline 08 & Aghchren de Elousseur ${ }^{\text {a.c }}$ & Setif & 56 & Derdouri $^{c}$ & Skikda \\
\hline 09 & Aghenfas $^{\text {a.c }}$ & Setif & 57 & El-Kharfic & Skikda \\
\hline 10 & Aghenfous $^{c}$ & Setif & 58 & Ferkania $^{\text {a.c }}$ & Tebessa \\
\hline 11 & Agrarez $^{\text {a.c }}$ & Bejaia & 59 & Gelb al faroudje $\mathrm{c}^{\mathrm{c}}$ & Batna \\
\hline 12 & Aguenaou $^{\text {a.c }}$ & Setif & 60 & Grosse de Hamma ${ }^{\text {a.c }}$ & Constantine \\
\hline 13 & Aharoun ${ }^{\text {a.c }}$ & Bouira & 61 & Guerboua b.d & El Taref \\
\hline 14 & Ahia-Ousbaaa ${ }^{c . d}$ & Khenchela & 62 & $\mathrm{Hamra}^{\mathrm{a} \cdot \mathrm{c}}$ & Jijel \\
\hline 15 & Ahorri $^{b}$ & Tizi-ouzou & 63 & Hamraya $^{\mathrm{b}}$ & Khenchela \\
\hline 16 & Aîmel ${ }^{\text {a.c }}$ & Bejaia & 64 & Hebraya $^{\mathrm{b}}$ & Khenchela \\
\hline 17 & Akenane $^{c . d}$ & Biskra & 65 & Ifiri $^{c}$ & Béjaia \\
\hline 18 & Akerma $^{\text {a.c }}$ & Bejaia & 66 & Issoual $^{\mathrm{b}}$ & Béjaia \\
\hline 19 & Akounyane $^{\mathrm{b}}$ & Tizi-ouzou & 67 & Kahlaya $^{\mathrm{b}}$ & Khenchela \\
\hline 20 & Alslith (Lasli) ${ }^{\text {b.d }}$ & Khenchela & 68 & Kerdoussi $^{\mathrm{c}}$ & Skikda \\
\hline 21 & Altifane $^{\mathrm{b}}$ & Setif & 69 & Laaninbic $^{c}$ & Skikda \\
\hline 22 & Amezzir ${ }^{\mathrm{b}}$ & Tizi-ouzou & 70 & Lahmarc $^{c}$ & Skikda \\
\hline 23 & Arihani $^{\mathrm{b}}$ & Tizi-ouzou & 71 & $\operatorname{Limli}^{\mathrm{a} . \mathrm{c}}$ & Bejaia \\
\hline 24 & Arjouni $^{\mathrm{b}}$ & Bouira & 72 & Lokchiric $^{\mathrm{c}}$ & Skikda \\
\hline 25 & Attounsi $^{\mathrm{c}}$ & Setif & 73 & Longue de Meliana ${ }^{\text {a.c }}$ & Ain defla \\
\hline 26 & Azeboudj de Ain Zaatout ${ }^{\mathrm{b} . \mathrm{d}}$ & Biskra & 74 & Mekki $^{\text {a.c }}$ & Khenchela \\
\hline 27 & Azeboudj Boudoudane ${ }^{\mathrm{c.d}}$ & Khenchela & 75 & Melissi $^{\text {b.d }}$ & Setif \\
\hline 28 & Azeboudj de Khirane $e^{b . d}$ & Khenchala & 76 & Neb jmel ${ }^{a . c}$ & Khenchela \\
\hline 29 & Azeboudj de Louandoura ${ }^{\text {b.d }}$ & Khenchala & 77 & Oukhelfab & Khenchela \\
\hline 30 & Azeradj $^{\text {a.c }}$ & Bejaia & 78 & Reyab $^{\mathrm{b}}$ & Khenchela \\
\hline 31 & Azeradj de Ain Zaatout ${ }^{\text {b.d }}$ & Biskra & 79 & Ronde de Meliana a.c & Ain defla \\
\hline 32 & Azeradj Tamorka ${ }^{c}$ & Setif & 80 & Rougette de Metidja ${ }^{\text {a.c }}$ & Blida \\
\hline 33 & Azevli $^{\mathrm{b}}$ & Tizi-ouzou & 81 & Rouihnic $^{\mathrm{c}}$ & Skikda \\
\hline 34 & Azizawth (Khadraïa) ${ }^{c . d}$ & Khenchela & 82 & Roujette de Fejouj b.d & Guelma \\
\hline 35 & Balbal $^{\mathrm{d}}$ & Skikda & 83 & Serradjb.d & Skikda \\
\hline 36 & Balbal2c & Skikda & 84 & Serti $^{\text {b.d }}$ & Skikda \\
\hline 37 & Barouni ${ }^{\text {b.d }}$ & El Taref & 85 & Sigoise $^{\text {a.c }}$ & Mascar \\
\hline 38 & Beskric $^{\mathrm{c}}$ & Batna & 86 & Souidi ${ }^{\text {a.c }}$ & Khenchela \\
\hline 39 & Blanquette de Castu ${ }^{c . d}$ & Guelma & 87 & Tabelout $^{\mathrm{a} \cdot \mathrm{c}}$ & Bejaia \\
\hline 40 & Blanquette de Guelma $a^{\text {a.c }}$ & Guelma & 88 & Takesrita.c & Bejaia \\
\hline 41 & Blilti $^{c}$ & Skikda & 89 & Talianib.d & El Taref \\
\hline
\end{tabular}


Continued

\begin{tabular}{llllll}
42 & Bouchouk $^{c}$ & Setif & 90 & Tefah $^{\text {a.c }}$ & Bejaia \\
43 & Bouchouk Guergour $^{\text {a }}$ & Setif & 91 & Telthi $^{\text {c }}$ & Batna \\
44 & Bouchouk Lafayette $^{\text {a.c }}$ & Setif & 92 & Thawraghth $^{\text {b }}$ & Setif \\
45 & Bouchouk Soummam $^{\text {a.c }}$ & Bejaia & 93 & Thazougaghth $^{\text {b }}$ & Setif \\
46 & Bouchouka $^{\text {b.d }}$ & Skikda & 94 & Zeletni $^{\text {a.c }}$ & Khenchela \\
47 & Boughefous $^{\text {a.c }}$ & Setif & 95 & Zitoune $^{\text {b }}$ & Skikda \\
48 & Bouguenfou $^{\text {b.d }}$ & Khenchela & & & \\
\hline
\end{tabular}

a : Cultivars described in the catalog of Algerian olive varieties (36 cultivars) (Mendil et Sebai, 2006).

b: Denominations never mentioned in the bibliography (33 denominations) (Original, 2020).

c: Denominations already characterized by molecular markers (60 denominations) ((Dominguez-Garcia et al., 2011; Haouane et al., 2011; Trujillo et al., 2013; Abdessemed et al., 2015; Boucheffa et al., 2016; Boucheffa et al., 2018; Di Rienzo et al., 2018).

d: Denominations sampled for morphological characterization in this work (23 denominations).

2015). However, almost all these new olive groves consist of either introduced cultivars or dominant Algerian cultivars (Chemlal, Sigoise ... etc). This action, although it has many positive points on the development of Algerian olive growing, it could worsen the situation of rare indigenous cultivars with very limited distribution.

\subsection{MORPHOLOGICAL CHARACTERISTICS}

Table $5 \mathrm{a}$ and Table $5 \mathrm{~b}$ summarize the results of the measurements carried out on 23 denominations studied. ANOVA test reveals very highly significant differences between the denominations for all traits studied. The coefficient of variation varies from a minimum of $9.84 \%$ for the character $\mathrm{PO} / \mathrm{OD}$ to a maximum of $55.36 \%$ for the character PO. The PN, NS, RPN and PO characters show high variations with values of $25.80 \%, 37.68 \%, 42.08 \%$ and $55.36 \%$ respectively.

The BAL denomination has the highest average for the characters PO, LO, DO, LN and DN $(8.66 \mathrm{~g}, 32.33 \mathrm{~mm}$ and $22.75 \mathrm{~mm}, 21.93 \mathrm{~mm}$ and $8.98 \mathrm{~mm}$ respectively), while the GUER denomination has the highest average for the RPN ratio and DN (9.84 and $9.73 \mathrm{~mm}$ respectively), and the lowest average for LN and LN/DN (12.44 mm and 1.29 respectively). The denominations GUER and BAL, with a large caliber, are widely distinguished from the other denominations, they are characterized by very superior quantitative values and they are very appreciated as table olive by the olive growers and local consumers. It should be noted that these two denominations are not very existent even in their growing regions.

The BOUG denomination is characterized by the lowest averages for PO, LO, DO, and LN $(1.50 \mathrm{~g}, 16.99 \mathrm{~mm}$, $12.01 \mathrm{~mm}, 12.59 \mathrm{~mm}$ respectively). In contrast, the SERR denomination has the lowest averages for PN and DN (0.28 $\mathrm{g}$ and $6.12 \mathrm{~mm}$, respectively). The SERT denomina- tion has the highest average for LN/DN and LO/DO ratios (2.60 and 1.62, respectively). The TAL denomination has the highest average for NS (10.51) while the AZIZ denomination has the lowest average for this trait (5.25). Finally, the SERR and AZB-E denominations are characterized by the lowest average for PN $(0.28 \mathrm{~g})$.

The denominations AHIA, AK, ALS, BAL, B-GASTU, CHET, GUER, R-FEJOUJ, TAL and SERR show the highest RPN character values. This character informs us about the richness of the fruit in pulp which is the main and most important part. Based on this trait, the denominations given could give important oil yield results or can be used as valuable table olive.

By using the morphological description of the denominations studied, based on 20 traits of the tree, the fruit and the endocarp, a morphological description is given in Table $6 \mathrm{a}$ and Table $6 \mathrm{~b}$ for the 23 denominations studied. This allowed us to give an identity for each of them and to differentiate them from those of the catalog of Algerian olive varieties which goes in favor of the hypothesis of unique cultivar of each denomination. This study allowed us to enrich the list of olive varieties that exist in Algeria with 33 candidate denominations that can constitute varieties in their own right. In this case, a study by molecular markers is necessary to detect cases of taxonomic confusion (synonymy or homonymy).

\subsubsection{Principal Component Analysis (PCA)}

Figure 2 shows the projection of the characters on the plane generated by the first two principal components accumulating $74.37 \%$ of total inertia. The variables PO, PN, LO, LN, DO, DN and LO/DO explain most of the variance on the first axis (negatively correlated). While the second axis is explained by the variables LN/DN, NS and RPN (correlated negatively). BAL and GUER de- 
Table 5a: Results relating to quantitative trait measurements

\begin{tabular}{|c|c|c|c|c|c|}
\hline Denomination & $\mathrm{PN}(\mathrm{g})^{* * *}$ & $\mathrm{LN}(\mathrm{mm})^{* * *}$ & $\mathrm{DN}(\mathrm{mm})^{* * *}$ & $\mathrm{LN} / \mathrm{DN} * * *$ & NS $* * *$ \\
\hline AHIA & $0.30 \pm 0.05 \mathrm{bc}$ & $14.10 \pm 2.21 \mathrm{~d}$ & $6.62 \pm 0.32 \mathrm{f}$ & $2.13 \pm 0.34 \mathrm{~g}$ & $6.10 \pm 1.21 \mathrm{~b}$ \\
\hline $\mathrm{AK}$ & $0.37 \pm 0.09 \mathrm{f}$ & $14.57 \pm 1.98 \mathrm{e}$ & $7.15 \pm 0.54 \mathrm{~h}$ & $2.04 \pm 0.22 \mathrm{e}$ & $7.37 \pm 1.14 \mathrm{c}$ \\
\hline ALS & $0.34 \pm 0.05 \mathrm{e}$ & $14.06 \pm 0.92 \mathrm{~cd}$ & $6.92 \pm 0.38 \mathrm{~g}$ & $2.04 \pm 0.19 \mathrm{e}$ & $8.61 \pm 1.36 \mathrm{~g}$ \\
\hline AZB-AZ & $0.29 \pm 0.05 \mathrm{ab}$ & $13.81 \pm 0.81 \mathrm{c}$ & $6.23 \pm 0.38 \mathrm{bcd}$ & $2.22 \pm 0.15 \mathrm{~h}$ & $7.43 \pm 1.00 \mathrm{c}$ \\
\hline AZB-B & $0.55 \pm 0.13 \mathrm{k}$ & $17.74 \pm 1.52 \mathrm{k}$ & $7.60 \pm 0.48 \mathrm{~m}$ & $2.34 \pm 0.17 \mathrm{mp}$ & $8.04 \pm 1.56 \mathrm{f}$ \\
\hline AZB-K & $0.38 \pm 0.05 \mathrm{f}$ & $15.91 \pm 2.12 \mathrm{~g}$ & $6.96 \pm 0.30 \mathrm{~g}$ & $2.29 \pm 0.33 \mathrm{~km}$ & $7.59 \pm 1.11 \mathrm{cde}$ \\
\hline AZB-E & $0.28 \pm 0.05 \mathrm{a}$ & $13.13 \pm 1.06 \mathrm{~b}$ & $6.2 \pm 0.43 \mathrm{abc}$ & $2.12 \pm 0.13 \mathrm{f}$ & $8.73 \pm 1.23 \mathrm{gh}$ \\
\hline AZIZ & $0.34 \pm 0.06 \mathrm{e}$ & $12.72 \pm 1.16 \mathrm{a}$ & $6.94 \pm 0.41 \mathrm{~g}$ & $1.83 \pm 0.13 \mathrm{c}$ & $5.25 \pm 1.17 \mathrm{a}$ \\
\hline BAL & $0.91 \pm 0.14 \mathrm{~s}$ & $21.93 \pm 1.63 \mathrm{p}$ & $8.98 \pm 0.85 \mathrm{~s}$ & $2.46 \pm 0.27 \mathrm{q}$ & $12.66 \pm 1.85 \mathrm{~s}$ \\
\hline BAR & $0.47 \pm 0.07 \mathrm{~h}$ & $15.90 \pm 1.33 \mathrm{~g}$ & $7.35 \pm 0.38 \mathrm{k}$ & $2.16 \pm 0.17 \mathrm{~g}$ & $9.91 \pm 1.21 \mathrm{p}$ \\
\hline ABS & $0.48 \pm 0.10 \mathrm{~h}$ & $15.87 \pm 2.23 \mathrm{~g}$ & $7.94 \pm 0.59 p$ & $2.00 \pm 0.26 \mathrm{de}$ & $7.53 \pm 1.55 \mathrm{~cd}$ \\
\hline B-GASTU & $0.32 \pm 0.06 \mathrm{de}$ & $14.98 \pm 1.30 \mathrm{f}$ & $6.35 \pm 0.39 \mathrm{e}$ & $2.36 \pm 0.21 \mathrm{p}$ & $8.65 \pm 1.44 \mathrm{~g}$ \\
\hline $\mathrm{BOUCH}$ & $0.71 \pm 0.09 \mathrm{q}$ & $19.06 \pm 1.37 \mathrm{~m}$ & $8.31 \pm 0.45 \mathrm{q}$ & $2.30 \pm 0.17 \mathrm{~km}$ & $7.49 \pm 1.78 \mathrm{c}$ \\
\hline BOUG & $0.31 \pm 0.31 \mathrm{ab}$ & $12.59 \pm 1.53 \mathrm{a}$ & $6.16 \pm 0.50 \mathrm{ab}$ & $2.04 \pm 0.16 \mathrm{e}$ & $9.14 \pm 1.98 \mathrm{k}$ \\
\hline CHET & $0.31 \pm 0.06 \mathrm{c}$ & $14.92 \pm 1.54 \mathrm{f}$ & $6.26 \pm 0.53 \mathrm{cde}$ & $2.47 \pm 1.34 \mathrm{p}$ & $9.01 \pm 1.57 \mathrm{hk}$ \\
\hline DER & $0.43 \pm 0.08 \mathrm{~g}$ & $14.22 \pm 1.13 \mathrm{~d}$ & $7.13 \pm 0.45 \mathrm{~h}$ & $2.00 \pm 0.14 \mathrm{~d}$ & $7.87 \pm 1.17 \mathrm{df}$ \\
\hline GUER & $0.69 \pm 0.13 p$ & $12.44 \pm 1.43 \mathrm{a}$ & $9.73 \pm 0.95 \mathrm{t}$ & $1.29 \pm 0.21 \mathrm{a}$ & $8.68 \pm 1.70 \mathrm{~g}$ \\
\hline MEL & $0.57 \pm 0.09 \mathrm{~m}$ & $16.67 \pm 1.05 \mathrm{~h}$ & $7.64 \pm 0.45 \mathrm{~m}$ & $2.19 \pm 0.15 \mathrm{gh}$ & $7.82 \pm 1.72 \mathrm{def}$ \\
\hline R-FEJOUJ & $0.29 \pm 0.05 \mathrm{abc}$ & $14.24 \pm 1.36 \mathrm{~d}$ & $6.24 \pm 0.34 \mathrm{bcd}$ & $2.29 \pm 0.22 \mathrm{k}$ & $9.59 \pm 1.58 \mathrm{~m}$ \\
\hline SERT & $0.56 \pm 0.07 \mathrm{~km}$ & $18.92 \pm 1.46 \mathrm{~m}$ & $7.30 \pm 0.34 \mathrm{k}$ & $2.60 \pm 0.20 \mathrm{~s}$ & $10.41 \pm 1.51 \mathrm{q}$ \\
\hline TAL & $0.31 \pm 0.03 \mathrm{~cd}$ & $15.63 \pm 0.94 \mathrm{~g}$ & $6.32 \pm 0.25 \mathrm{de}$ & $2.48 \pm 0.17 \mathrm{q}$ & $10.51 \pm 1.35 \mathrm{q}$ \\
\hline SERR & $0.28 \pm 0.05 \mathrm{a}$ & $14.90 \pm 1.21 \mathrm{f}$ & $6.12 \pm 0.37 \mathrm{a}$ & $2.44 \pm 0.18 \mathrm{q}$ & $10.43 \pm 1.54 \mathrm{q}$ \\
\hline AZR & $0.33 \pm 0.05 \mathrm{e}$ & $12.77 \pm 0.94 \mathrm{a}$ & $7.34 \pm 0.31 \mathrm{k}$ & $1.74 \pm 0.14 \mathrm{~b}$ & $7.48 \pm 0.99 c$ \\
\hline $\mathrm{CV} \%$ & 42.08 & 17.42 & 13.74 & 15.02 & 25.80 \\
\hline$p$-value & $<0.001$ & $<0.001$ & $<0.001$ & $<0.001$ & $<0.001$ \\
\hline
\end{tabular}

***: very highly significant ANOVA result (alpha $=0.05)$

a, b, c, d, e, f...: homogeneous groups

nominations are not included in this analysis because they have extreme values.

The PCA also shows the grouping of the characters studied into two groups. The first includes the characters DN, PN, LO / DO LN, LO, PO and DO. The second group contains the characters LN / DN, NS and RPN.

Projection of individuals (Figure 3 ) shows that the denominations AZB-B, ABS, BOUCH and SERT are characterized by the highest values for the characters $\mathrm{PO}, \mathrm{PN}, \mathrm{LO}, \mathrm{LN}, \mathrm{DO}, \mathrm{DN}$ and LO/DO. In contrast, the denominations AZB-AZ, AZB-E and BOUG are characterized by the lowest values for these same traits. The B-GASTU, CHET, R-FEJOUJ, TAL and SERR denominations show high NS, LN/DN and RPN, while the AZIZ, DER, MEL and AZR denominations show reduced values for the same characters.

The results of PCA show that it is possible to dis- tinguish between the denominations using the characters of the fruit, the endocarp, in particular: $\mathrm{PN}, \mathrm{LN}$, DN, LN / DN, LO, PO and RPN. On another side, the grouping of characters by the PCA into two groups can most probably be a reflection of a pleiotropic effect and therefore exploitable for possible genetic improvement tests.

For the denominations $\mathrm{AZB}-\mathrm{B}, \mathrm{ABS}, \mathrm{BOUCH}$ and SERT, despite the high values of mass, length and width of the fruits, their interest is affected by the high values of the endocarp for these same characters, which also results in lower RPNs. On the other hand the denominations AZB-AZ, AZB-E and BOUG record reduced values for these same characters of the fruit, which can be explained by the fact that they are feral forms, not cultivated and not exploited because either of their small fruits or their relatively large endocarp. 
Table 5b: Results relating to quantitative trait measurements

\begin{tabular}{|c|c|c|c|c|c|}
\hline Denomination & $\mathrm{PO}(\mathrm{g})^{* * *}$ & $\mathrm{LO}(\mathrm{mm})^{* * *}$ & $\mathrm{DO}(\mathrm{mm})^{* * *}$ & $\mathrm{LO} / \mathrm{DO}^{* * *}$ & $\mathrm{RPN}^{* * *}$ \\
\hline AHIA & $2.63 \pm 0.57 \mathrm{k}$ & $20.40 \pm 2.19 \mathrm{f}$ & $15.17 \pm 1.02 \mathrm{~m}$ & $1.35 \pm 0.13 \mathrm{fg}$ & $7.88 \pm 1.91 \mathrm{p}$ \\
\hline $\mathrm{AK}$ & $2.99 \pm 0.56 \mathrm{~m}$ & $21.17 \pm 2.09 \mathrm{hk}$ & $16.34 \pm 1.14 \mathrm{~s}$ & $1.30 \pm 0.10 \mathrm{~b}$ & $7.40 \pm 1.81 \mathrm{~km}$ \\
\hline ALS & $2.68 \pm 0.39 \mathrm{k}$ & $20.45 \pm 1.42 \mathrm{f}$ & $15.44 \pm 0.80 \mathrm{p}$ & $1.33 \pm 0.08 \mathrm{de}$ & $6.97 \pm 1.40 \mathrm{~h}$ \\
\hline AZB-AZ & $1.72 \pm 0.23 \mathrm{~b}$ & $18.23 \pm 1.01 \mathrm{~b}$ & $13.05 \pm 0.75 \mathrm{c}$ & $1.40 \pm 0.07 \mathrm{mp}$ & $5.14 \pm 1.40 \mathrm{e}$ \\
\hline AZB-B & $3.51 \pm 0.52 \mathrm{q}$ & $24.75 \pm 1.53 \mathrm{~s}$ & $15.82 \pm 0.76 \mathrm{q}$ & $1.57 \pm 0.08 \mathrm{t}$ & $5.68 \pm 1.44 \mathrm{fg}$ \\
\hline AZB-K & $2.10 \pm 0.36 \mathrm{de}$ & $20.87 \pm 2.19 \mathrm{gh}$ & $13.37 \pm 0.85 \mathrm{~d}$ & $1.56 \pm 0.16 \mathrm{t}$ & $4.62 \pm 1.14 \mathrm{~d}$ \\
\hline AZB-E & $1.64 \pm 0.24 \mathrm{~b}$ & $17.87 \pm 1.06 \mathrm{~b}$ & $12.56 \pm 0.70 \mathrm{~b}$ & $1.42 \pm 0.06 \mathrm{q}$ & $5.00 \pm 1.23 \mathrm{e}$ \\
\hline AZIZ & $2.18 \pm 0.43 \mathrm{e}$ & $18.62 \pm 1.46 \mathrm{~d}$ & $14.37 \pm 0.97 \mathrm{~g}$ & $1.30 \pm 0.09 \mathrm{bc}$ & $5.61 \pm 1.38 \mathrm{f}$ \\
\hline BAL & $8.66 \pm 1.27 \mathrm{t}$ & $32.33 \pm 1.81 \mathrm{u}$ & $22.75 \pm 1.27 \mathrm{u}$ & $1.42 \pm 0.08 \mathrm{q}$ & $8.71 \pm 2.04 \mathrm{q}$ \\
\hline BAR & $2.45 \pm 0.32 \mathrm{gh}$ & $20.50 \pm 1.81 \mathrm{fg}$ & $14.82 \pm 0.69 \mathrm{~h}$ & $1.38 \pm 0.10 \mathrm{~km}$ & $4.29 \pm 1.06 \mathrm{c}$ \\
\hline ABS & $3.27 \pm 0.62 \mathrm{p}$ & $22.58 \pm 2.07 \mathrm{q}$ & $16.55 \pm 1.06 \mathrm{t}$ & $1.37 \pm 0.12 \mathrm{ghk}$ & $5.99 \pm 1.34 \mathrm{~g}$ \\
\hline B-GASTU & $3.09 \pm 0.50 \mathrm{~m}$ & $21.74 \pm 1.65 \mathrm{p}$ & $16.19 \pm 0.86 \mathrm{~s}$ & $1.34 \pm 0.09 \mathrm{ef}$ & $8.67 \pm 1.75 \mathrm{q}$ \\
\hline BOUCH & $3.34 \pm 0.66 \mathrm{p}$ & $24.64 \pm 1.76 \mathrm{~s}$ & $16.19 \pm 1.23 \mathrm{~s}$ & $1.52 \pm 0.08 \mathrm{~s}$ & $3.81 \pm 1.12 \mathrm{~b}$ \\
\hline BOUG & $1.50 \pm 0.40 \mathrm{a}$ & $16.99 \pm 1.88 \mathrm{a}$ & $12.01 \pm 1.08 \mathrm{a}$ & $1.41 \pm 0.08 \mathrm{pq}$ & $4.51 \pm 1.35 \mathrm{~cd}$ \\
\hline CHET & $2.46 \pm 0.66 \mathrm{gh}$ & $20.30 \pm 2.44 \mathrm{f}$ & $14.87 \pm 1.34 \mathrm{hk}$ & $1.36 \pm 0.08 \mathrm{gh}$ & $7.01 \pm 1.83 \mathrm{~h}$ \\
\hline DER & $1.93 \pm 0.40 \mathrm{c}$ & $18.81 \pm 1.67 \mathrm{~d}$ & $13.71 \pm 1.08 \mathrm{e}$ & $1.37 \pm 0.09 \mathrm{hk}$ & $3.66 \pm 1.22 \mathrm{ab}$ \\
\hline GUER & $7.21 \pm 1.03 \mathrm{~s}$ & $25.53 \pm 1.47 \mathrm{t}$ & $22.96 \pm 1.12 \mathrm{u}$ & $1.11 \pm 0.06 \mathrm{a}$ & $9.84 \pm 2.31 \mathrm{~s}$ \\
\hline MEL & $2.49 \pm 0.34 \mathrm{~h}$ & $21.62 \pm 1.29 \mathrm{mp}$ & $14.13 \pm 0.85 \mathrm{f}$ & $1.53 \pm 0.09 \mathrm{~s}$ & $3.44 \pm 0.78 \mathrm{a}$ \\
\hline R-FEJOUJ & $2.35 \pm 0.43 \mathrm{fg}$ & $19.66 \pm 1.80 \mathrm{e}$ & $14.97 \pm 0.93 \mathrm{hk}$ & $1.31 \pm 0.11 \mathrm{~cd}$ & $7.13 \pm 1.65 \mathrm{hk}$ \\
\hline SERT & $3.38 \pm 0.52 \mathrm{p}$ & $25.43 \pm 1.56 \mathrm{t}$ & $15.67 \pm 0.86 \mathrm{q}$ & $1.62 \pm 0.08 \mathrm{u}$ & $5.15 \pm 1.15 \mathrm{e}$ \\
\hline TAL & $2.62 \pm 0.37 \mathrm{k}$ & $21.32 \pm 1.20 \mathrm{~km}$ & $15.07 \pm 0.82 \mathrm{~km}$ & $1.42 \pm 0.07 \mathrm{pq}$ & $7.49 \pm 1.41 \mathrm{~m}$ \\
\hline SERR & $2.30 \pm 0.58 \mathrm{f}$ & $20.23 \pm 2.05 \mathrm{f}$ & $14.30 \pm 1.36 \mathrm{fg}$ & $1.42 \pm 0.08 \mathrm{pq}$ & $7.30 \pm 2.08 \mathrm{hkm}$ \\
\hline AZR & $1.98 \pm 0.18 \mathrm{~cd}$ & $18.58 \pm 0.91 \mathrm{~cd}$ & $14.31 \pm 0.51 \mathrm{fg}$ & $1.30 \pm 0.07 \mathrm{bc}$ & $5.11 \pm 1.00 \mathrm{e}$ \\
\hline CV \% & 55.36 & 16.80 & 16.65 & 9.84 & 37.68 \\
\hline$p$-value & $<0.001$ & $<0.001$ & $<0.001$ & $<0.001$ & $<0.001$ \\
\hline
\end{tabular}

${ }^{* * *}$ : very highly significant ANOVA result (alpha $\left.=0.05\right)$;

$\mathrm{a}, \mathrm{b}, \mathrm{c} . .$. : homogeneous groups

\subsubsection{Multiple Correspondence Analysis (MCA)}

Based on qualitative traits, the MCA (Figure 4) ranks the 23 denominations in five (05) groups:

Group 1: composed by GUER denomination characterized by slightly asymmetric endocarp in position $\mathrm{B}$ and symmetrical fruits in position $\mathrm{A}$.

Group 2: composed by AHIA and AZB-K denominations which are characterized by fruits with nipples.

Group 3: composed by denominations AK, AZIZ, AZB-E, ABS, BOUG and AZR which are characterized by symmetrical endocarp in position $\mathrm{B}$, and slightly asymmetric fruits in position $A$ with a central position of the maximum diameter and a rounded form of the summit without nipple.

Group 4: composed by ALS, AZB-AZ, BAR, CHET, DER, MEL, R-FEJOUJ and SERT denominations which are characterized by slightly asymmetric endocarp in position $A$ and symmetrical in position $B$ with a rough surface.

Group 5: composed by denominations AZB-B, BAL, BOUCH, B-GASTU, TAL and SERR which are characterized by endocarps slightly asymmetric in position A, symmetrical in position $B$ with a central position of maximum transverse diameter and a pointed form of the summit, and fruits with a central position of the maximum transverse diameter and trees with strong vigor.

\subsubsection{Ascending Hierarchical Classification (AHC)}

The ascending hierarchical classification with morphological data (Figure 5) produces a dendrogram representing the 23 denominations classified into six (06) different groups: 


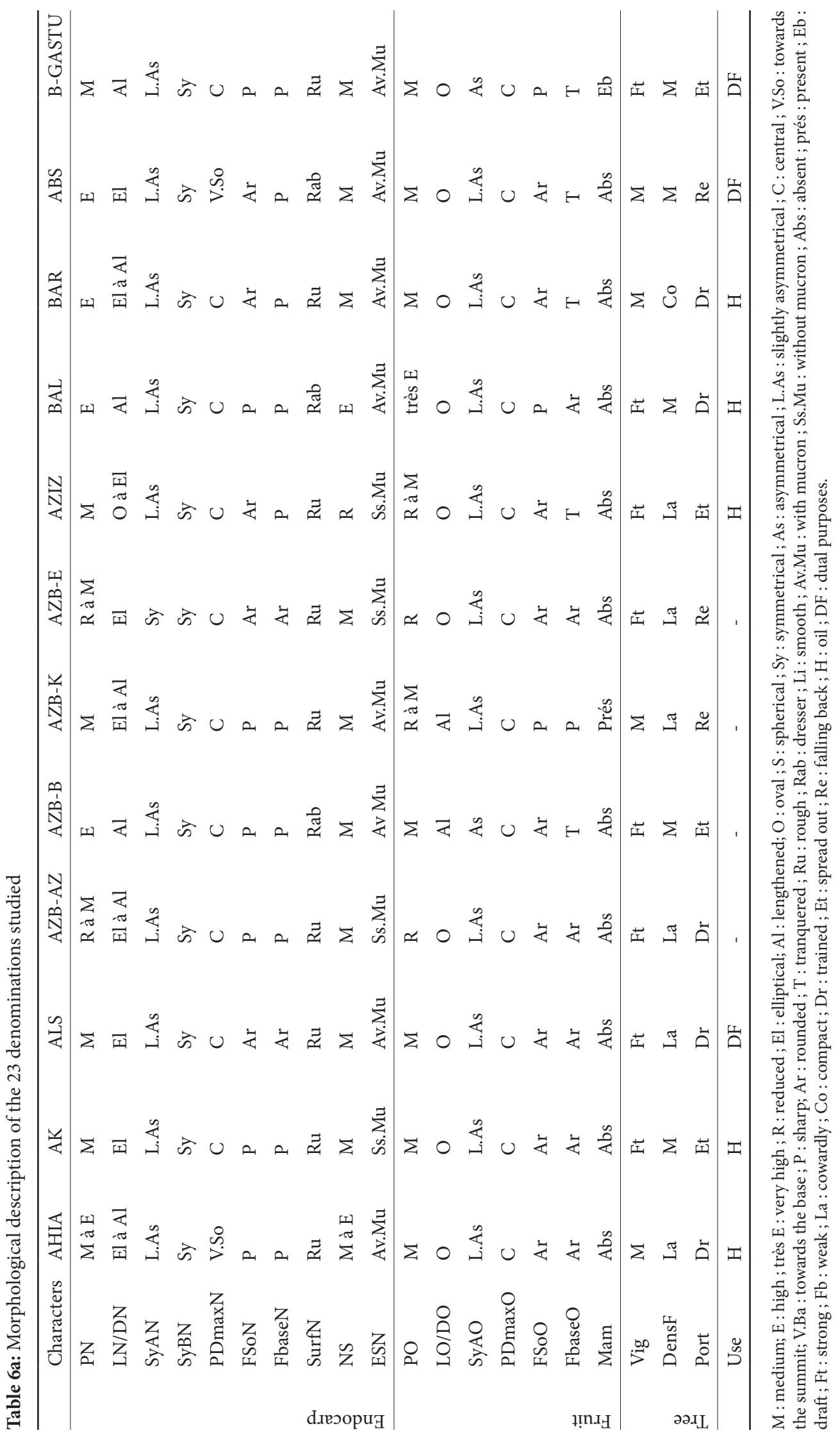




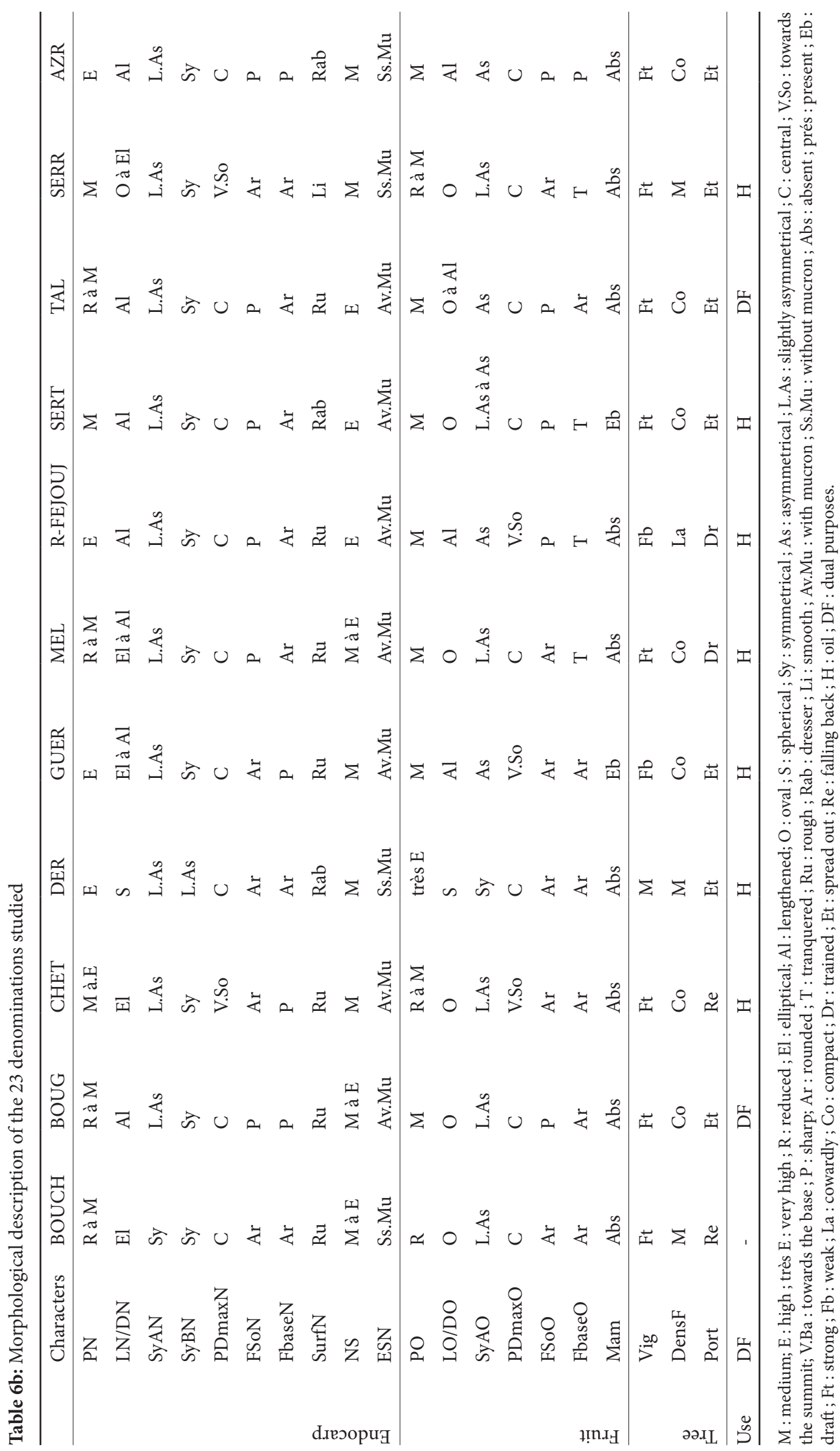




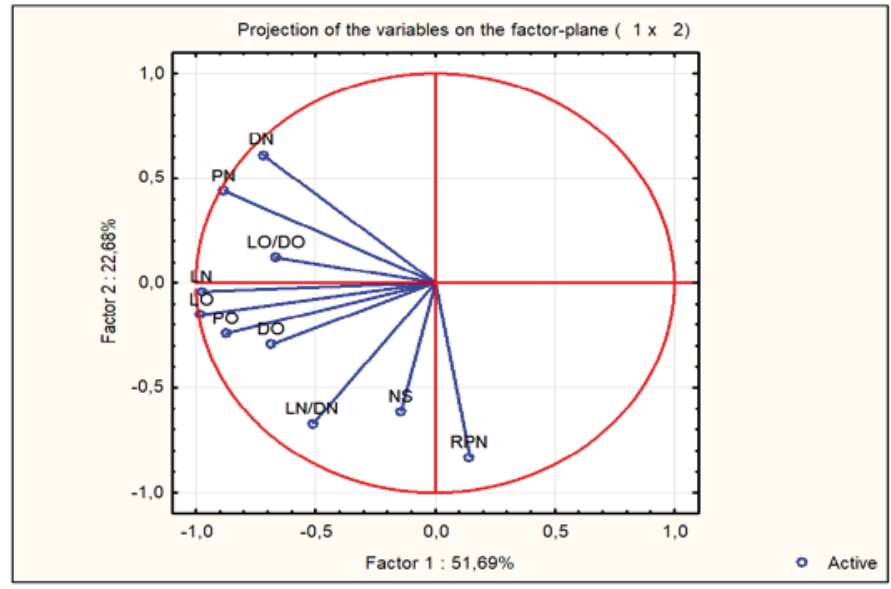

Figure 2: Projection of characters on the plane generated by the first two main components (PCA)

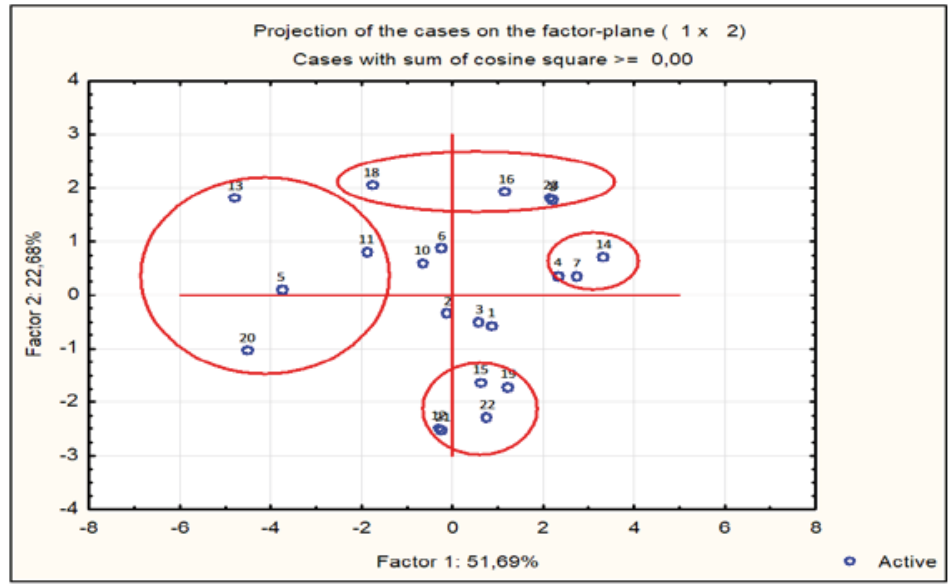

Figure 3: Projection of individuals on the plane generated by the first two main components (PCA).

(1): Ahia ousbaa ; (2) : Akenane ; (3) : Alslith ; (4) : Azeboudj de Ain Zaatout; (5) : Azeboudj Boudhoudhane; (6) : Azeboudj de Khirane; (7): Azeboudj de Elouandoura; (8) : Azizawth; (9) : Balbal ; (10) : Barouni ; (11) : Abeskri de Ain Zaatout ; (12) : Blanquette de Gastu; (13) : Bouchouka ; (14) : Bouguenfou ; (15) : Chetoui ; (16) : Derdi ; (17) : Guerboua ; (18) : Melissi ; (19) : Rougette de Fejouj ; (20): Serti ; (21) : Taliani ; (22) : Serradj ; (23) : Azerradj de Ain Zaatout.

Group 1: composed only by the BAL denomination that is characterized by the highest values for the majority of the characters except for $\mathrm{LO} / \mathrm{DO}$.

Group 2: composed only by the GUER denomination that is characterized by high values for PO, LO, DO, $\mathrm{PN}, \mathrm{LN}, \mathrm{DN}$. This denomination is also characterized by reduced values for $\mathrm{LO} / \mathrm{DO}$ and $\mathrm{LN} / \mathrm{DN}$.

Group 3: composed by the three denominations: BAR, MEL and AZB-K that are characterized by high LO/DO, LN/DN and reduced RPN ratio.

Group 4: composed by six denominations: AZIZ, AZR, DER, BOUG, AZB-E and AZB-AZ that are characterized by reduced values for PO, PN, LO, LN, DO and DN.

Group 5: composed by three denominations: AZB-
B, BOUCH and SERT which are characterized by a high $\mathrm{PO}, \mathrm{LO}, \mathrm{DO}$ and LO/DO. On the other hand, they have reduced $\mathrm{RPN}$ ratio.

Group 6: composed by the nine remaining denominations (09) namely: AHIA, AK, ALS, ABS, B-GASTU, CHET, R-FEJOUJ, TAL and SERR. These denominations are characterized by intermediate values for PO, LO, DO $\mathrm{LO} / \mathrm{DO}$ and $\mathrm{LN}$.

The results of the Ascending Hierarchical Classification are consistent with those obtained by principal components analysis. These two tests (based on quantitative traits), with Multiple Correspondence Analysis (based on qualitative characteristics) classified the 23 denominations into five to six groups with relatively similar morphological characteristics. 


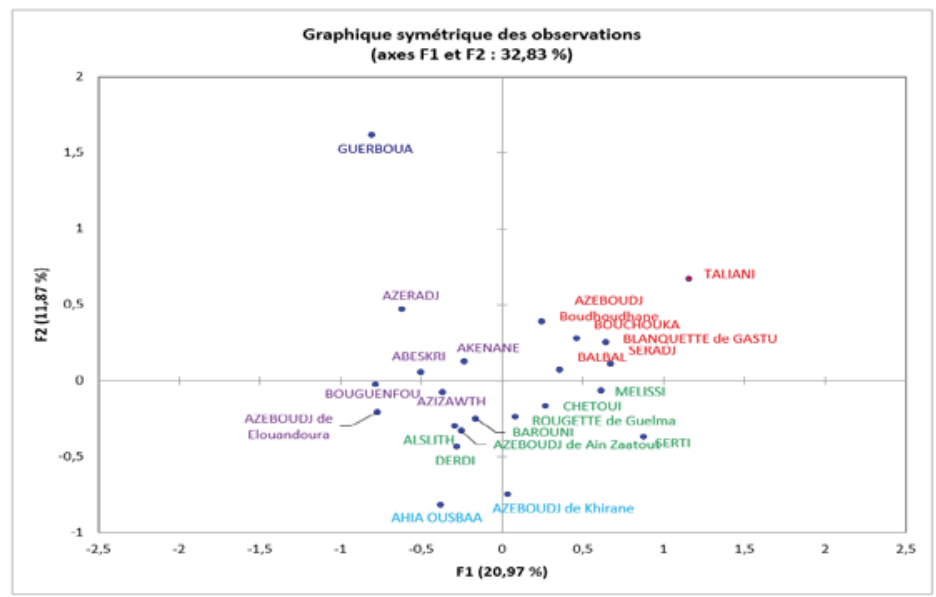

Figure 4: Multiple correspondence analysis (MCA) of the 23 denominations.

(1): Ahia ousbaa ; (2) : Akenane ; (3) : Alslith ; (4) : Azeboudj de Ain Zaatout; (5) : Azeboudj Boudhoudhane; (6) : Azeboudj de Khirane; (7) : Azeboudj de Elouandoura; (8) : Azizawth; (9) : Balbal ; (10) : Barouni ; (11) : Abeskri de Ain Zaatout ; (12) : Blanquette de Gastu; (13) : Bouchouka ; (14) : Bouguenfou ; (15) : Chetoui ; (16) : Derdi ; (17) : Guerboua ; (18) : Melissi ; (19) : Rougette de Fejouj ; (20): Serti ; (21): Taliani ; (22) : Serradj ; (23): Azerradj de Ain Zaatout.

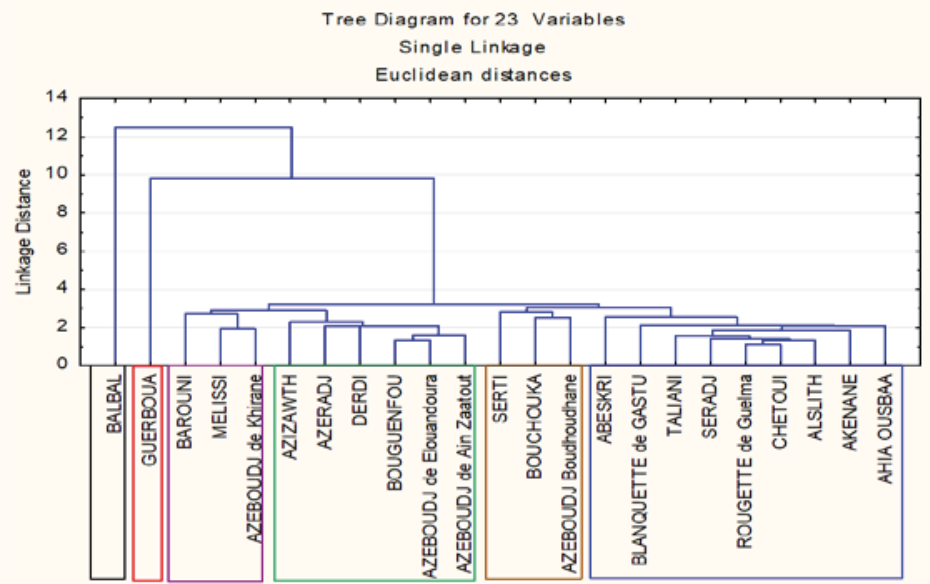

Figure 5: Ascending hierarchical classification (AHC)

(1) : Ahia ousbaa ; (2) : Akenane ; (3) : Alslith ; (4) : Azeboudj de Ain Zaatout; (5) : Azeboudj Boudhoudhane; (6) : Azeboudj de Khirane; (7): Azeboudj de Elouandoura; (8) : Azizawth; (9) : Balbal ; (10) : Barouni ; (11) : Abeskri de Ain Zaatout ; (12) : Blanquette de Gastu; (13) : Bouchouka ; (14) : Bouguenfou ; (15) : Chetoui ; (16) : Derdi ; (17) : Guerboua ; (18) : Melissi ; (19) : Rougette de Fejouj ; (20) : Serti ; (21) : Taliani ; (22) : Serradj ; (23) : Azerradj de Ain Zaatout.

\subsubsection{Diversity Index (Shannon-Weaver)}

The Shannon-Weaver relative diversity indices (J) of all traits and denominations as well as the means are presented in Table 7.

The average relative diversity of all denominations and characters is 0.42 .

The characters NS, SyAO, and SyAN have the highest average values of relative diversity $(0.63,0.66$, and 0.73 respectively), followed by $\mathrm{PN}, \mathrm{LN} / \mathrm{DN}, \mathrm{LO} / \mathrm{OD}$, FbaseO, $\mathrm{PDmaxN}$, and FbaseN which have lower average values (between 0.42 for PDmaxN and 0.54 for LO/OD). The other characters have low average values (between 0.24 for SyBN and 0.35 for FsomO and FsomN).

The denominations AHIA, AK, AZB-K and BOUG have the highest average values of relative diversity (between 0.55 and 0.58 ). The other denominations are characterized by lower mean values (between 0.31 for GUER and 0.47 for ALS).

The average relative diversity of all denominations obtained (0.42) is lower than that recorded by (Sidhoum et al., 2018) who conducted studies on samples composed of local and introduced denominations in western Algeria, and by (Laaribi et al., 2014) on hybrids of Chemlali in 


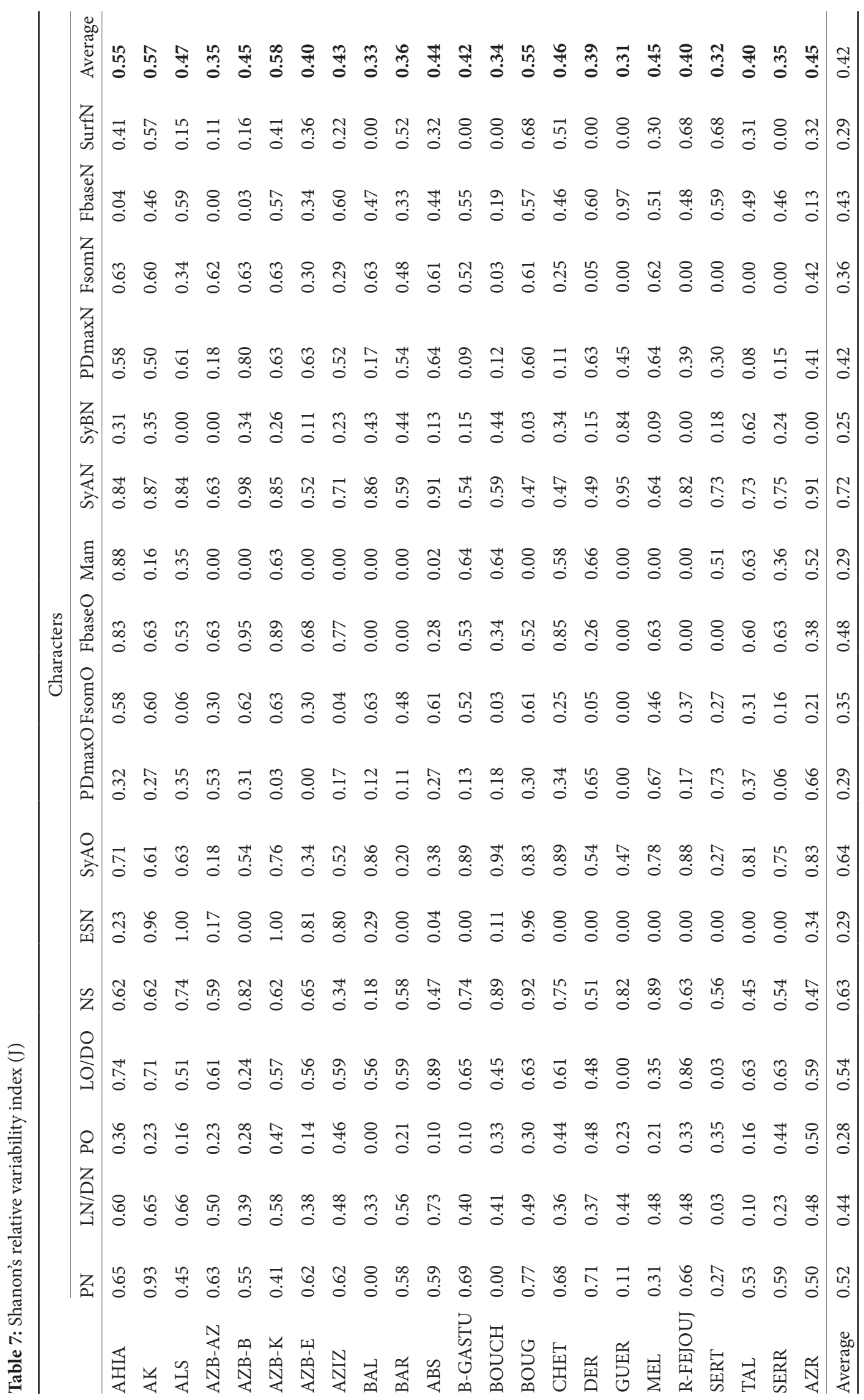


Tunisia (self-pollinations and cross-pollinations with local and introduced denominations). The diversity index can inform us about the degree of selection to which the different characters studied are submitted. In fact a high diversity index obtained for the characters: NS, SyAO, and SyAN will probably be due to a weak selection and/or genes that code for not very important characters, while a low diversity index obtained for the rest of the characters could be explained by either a strong selection and/or by genes which code for important characters. The highest average values of relative diversity obtained for the denominations AHIA, AK, AZB-K and BOUG can be explained by the fact that denominations AHIA and AK are less subject to selection and/or spread over more diverse environments than other denominations, while for AZB$\mathrm{K}$ and BOUG this is explained by the fact that they are feral forms and therefore not subject to selection.

\section{CONCLUSIONS}

Native olive resources are of considerable interest in the development of the olive sector in Algeria. This work aims to update and provide as much information as possible about the diversity of olive denominations using morphological characters.

Field surveys in several regions of central and eastern Algeria led to the registration of 33 denominations never mentioned in the bibliography. This number does not obviously reflect the actual number of existing denominations because several other regions are not yet prospected and cases of synonymy and homonymy can exist between different denominations. Morphological characterization allowed a morphological description based on the characters of the tree, fruit, and endocarp of the 23 denominations studied, and principal component analysis and ascending hierarchical classification allowed to classify them into six groups. The value of the relative diversity of all denominations is slightly below the average (0.42).

The results obtained in this work provide very useful information on the richness of Algerian olive resources and on certain morphological characteristics of the studied denominations, but only a genetic characterization by the molecular markers could confirm or invalidate the unique genetic identity of each denomination (a project of characterization by the SSRs markers is in progress).

Finally, in view of the critical conditions and the situation in which many of these denominations are found, it is urgent and imperative to carry out programs of introduction and preservation in-situ and ex-situ of these olive-growing resources, in particular those of Khirane and Ain Zaatout (wilaya of Khenchela and wilaya of
Biskra respectively) which are in very extreme environmental conditions.

\section{ACKNOWLEDGEMENTS}

This work was carried out with the help of:

S. Keciri (ITAF Sidi Aich), N. Boutemine (ITAF Constantine), O. Bougamouza (ITAF Skikda), Hamzaoui (DSA Khenchela), L. Fendali and L. Ababsa (subdivision agricole, Chechar, Khenchela), N. Hassani frome the village Ain Zaatout (Biskra), M. Chebah frome the village Khirane (Khenchela), A. M. Amziane and S. Abadlia.

\section{REFERENCES}

Abdessemed, S., Muzzalupo, I., Benbouza, H. (2015). Assessment of genetic diversity among Algerian olive (Olea europaea L.) cultivars using SSR marker. Scientia Horticulturae, 192, 10-20. https://doi.org/10.1016/j.scienta.2015.05.015.

Abdessemed, S., Abdessemed, A., Boudchicha, R.H., Benbouza, H. (2018). Caractérisation et identification de quelques écotypes d'olivier (Olea europaea L.) en Algérie. Agriculture Biannual journal, edited by Ferhat ABBAS University, Sétif1, 8(2), 26-43.

Alloum, D. (1974). Loléiculture algérienne. CIHEAM Options Méditerranéennes, n 24, 45-48. https://doi.org/10.1093/ bioscience/24.1.45

Barranco D, Cimato A, Fiorino P, Rallo L, Touzani A, Castañeda C, Serafini F, Trujillo I (2000a). World olive catalogue of olive varieties. International Olive Oil Council, Madrid, Spain.

Boucheffa, S., Miazzi, M.M., di Rienzo, V., Mangini, G., Fanelli, V., Tamendjari, A., Pignone, D., Montemurro, C. (2016). The coexistence of oleaster and traditional varieties affects genetic diversity and population structure in Algerian olive (Olea europaea L.) germplasm. Genetic Resources and Crop Evolution. https://doi.org/10.1007/s10722-016-0365-4.

Boucheffa, S., Tamendjari, A., Sanchez-Gimeno, A.C., Rovellini, P., Venturini, S., di Rienzo, V., Miazzi, M.M., Montemurro, C. (2018). Diversity assessment of Algerian wild and cultivated olives (Olea europeae L.) by molecular, morphological, and chemical traits. European Journal of Lipid Science and Technology. https://doi.org/10.1002/ejlt.201800302.

Boukhari, R., Gaouar, S.B.S. (2018). Caractérisation de quelques variétés d’olivier Algériennes (TiziOuzou). Editions Universitaires Européennes ISBN 978-3-639-54678-1.

Merlin Alfred. Henriette Camps Fabrer. (1954). Lolivier et l'huile dans l'Afrique romaine (Gouvernement Général de l'Algérie, Direction de l'Intérieur et des Beaux-Arts, Service des Antiquités, Missions archéologiques). In: Journal des savants. p. 139. Retrieved from http://www.persee.fr/doc/ jds_0021-8103_1954_num_3_1_3310_t1_0139_0000_1.

di Rienzo V, Sion S, Taranto F, D’Agostino N, Montemurro C, Fanelli V, ... Miazzi MM. 2018. Genetic flow among olive 
populations within the Mediterranean basin. PeerJ Life and Environment 6:e5260 https://doi.org/10.7717/peerj.5260.

Dominguez-Garcia, M.C., Laib, M., De La Rosa, R., Belaj, A. (2011). Characterisation and identification of olive denominations from North-eastern Algeria using molecular markers. The Journal of Horticultural Science and Biotechnology. https://doi.org/10.1080/14620316.2012.11512837.

Frah, N., Baala, H., Loucif, A. (2015). Etude de l'arthropodofane dans un verger dolivier à Sefiane (W. Batna Est - Algérie). Lebanese Science Journal, 16(2).

Haouane, H., El Bakkali, A., Moukhli, A., Tollon, C., Santoni, S., Oukabli, A., El Modafar, C., Khadari, B. (2011). Genetic structure and core collection of the World Olive Germplasm Bank of Marrakech: towards the optimised management and use of Mediterranean olive genetic resources. Genetica. https://doi.org/10.1007/s10709-011-9608-7.

Hauville, A. (1953). La répartition des variétés d'olives en Algérie et ses Conséquences pratiques. Bulletin de la société des Agriculteurs d'Algérie, 580.

Laaribi, I., Mezghani, A.M., Mars, M. (2014). Phenotypic diversity of some olive tree progenies issued from a Tunisian breeding program. European Scientific Journal, 10(6), 1857-7881.

Mendil, M., Sebai, A. (2006). Catalogue des variétés Algériennes de l'olivier. Institut Technique de l'Arboriculture Fruitière et de la vigne (ITAF). dépôt légal Nº1840 2006. 99p.

Morizot, P. (1993). L'Aurès et l'olivier. Antiquités africaines, 29(1), 177-240. https://doi.org/10.3406/antaf.1993.1219
Poljuha, D., Sladonja, B., Šetić, E., Milotić, A., Bandelj, D., Jakše, J., Javornik, B. (2008). DNA fingerprinting of olive varieties in Istria (Croatia) by microsatellite markers. Scientia Horticulturae, 115(3), 223-230. https://doi:10.1016/j.scienta.2007.08.018.

Shannon, C.E., Weaver, W. (1964). The mathematical theory of communication. The university of Illinois Press. Urbana. 125.

Sidhoum, M., Mahdad, M.Y., Meghelli, I., Bellatreche, A., Draoui, M., Gaouar, S.B.S. (2018). Genetic diversity analysis by the morphometric tool of some olive tree (Olea europaea L.) varieties in Western Algeria. International Journal of Biosciences (IJB). http://dx.doi.org/10.12692/ijb/12.2.1425.

Sidhoum, M., Gaouar, S.B.S. (2013). Effect of pedological nature on morphological characters of some olive-tree varieties from wilaya of Tlemcen. Science and Nature, 3(1), 25-32.

Sidhoum, M., Gaouar, S.B.S. (2017). Diversité oliécole au niveau de la wilaya de Tlemcen. Editions universitaires européennes. ISBN 978-3-639-60770-3.

Trujillo, I., Ojeda, M.A., Urdiroz, N.M., Potter, D., Barranco, D., Rallo, L., Diez, C.M. (2013). Identification of the worldwide olive germplasm bank of Córdoba (Spain) using SSR and morphological markers. Tree Genetics \& Genomes. https:// doi.org/10.1007/s11295-013-0671-3. 